\title{
Biofuel Production from the Orbetello Lagoon Macrophytes: Efficiency of Lipid Extraction Using Accelerate Solvent Extraction Technique
}

\author{
Monia Renzi ${ }^{1}$, Andrea Giovani ${ }^{2}$, Silvano E. Focardi ${ }^{2}$ \\ ${ }^{1}$ Department of Biological and Environmental Sciences and Technologies, University of the Salento, SP Lecce-Monteroni, Lecce, \\ Italy; ${ }^{2}$ Department of Physical, Earth and Environmental Sciences, University of Siena, Via Mattioli 4, Siena, Italy. \\ Email: monia.renzi@unisalento.it
}

Received August $2^{\text {nd }}, 2013$; revised September $5^{\text {th }}$, 2013; accepted October $4^{\text {th }}, 2013$

Copyright (C) 2013 Monia Renzi et al. This is an open access article distributed under the Creative Commons Attribution License, which permits unrestricted use, distribution, and reproduction in any medium, provided the original work is properly cited.

\begin{abstract}
In this paper, the efficiency of lipid extraction from macrophytes (Chaetomorpha linum, Ulva laetevirens, Valonia aegagrophyla, Gracilariopsis longissima, Ruppia cirrhosa) for the biodiesel production is evaluated using four different methods based on the Accelerated Solvent Extraction technique. Both wet and dried tissues are extracted and effects induced on lipid recovery by the pressure and the solvent mixture selection are evaluated. Results evidenced that better extraction performance is obtained using a polar/hydrophobic solvent mixture $(1: 1 \mathrm{v} / \mathrm{v})$. Accelerate Solvent Extraction technique significantly improves the total amount of lipid extracted from macrophytes tissues even if average values are about $2 \%$ of the dry weight. Observed efficiencies are far from the productive standards required by the industrial process; nevertheless, lipid extraction from macrophytes could represent an interesting step of a much more complex biomass recycling process which could include, besides biodiesel, also, the production of other commercial materials as well as pigments and biosorbents.
\end{abstract}

Keywords: Biodiesel Production; Macroalgae; Orbetello Lagoon; AS

\section{Introduction}

The possibility to produce renewable biofuels as well as methane and biodiesel by the extraction of oils from aquatic microalgae represents a target of particular scientific [1], commercial [2,3] and environmental concern due to the chance to substitute a meaningful share of fossil fuels, reducing greenhouse gas emissions, achieving efficiency and sustainability [4]. About the $78 \%$ of the energy production companies in America and the 13\% in Europe actually extract oils from microalgae [5]. Under controlled culture conditions, the efficiency of oil production by microalgae could represent a real alternative to petrol [6]. Efficiency observed in uncontrolled natural systems is low principally due to the high variability of biomass quality and the total amount of oils extracted [7]. For this reason, researches were focalized on artificial controlled ecosystems [5]. In spite of that, natural aquatic and uncontrolled ecosystems (i.e. coastal lagoons and estuaries) evidence a natural tendency to eutrophic conditions and high primary productivity rates. In this ecosys- tem the biomass production does not require additional energy supplies because it is naturally induced. Furthermore, to avoid possible alterations of the water quality, macroalgae are mechanically harvested and these management actions need important human actions supported by notable economic resources. As example, in the Orbetello lagoon (Italy), between 2002 and 2006 on average 27098.02 tons of macroalgae have been harvested (6774 tons/year) [8] with an associated expense of about 600,000 euros/year [9]. In these ecosystems, the chance to transform an actual important economic expense into a possible resource represents an interesting field for administrators and researchers. A recent research performed to compare energetic and economic sustainability of oil extraction yields evidenced that the production of oil from sunflower seeds is feasible with respect to macroalgae. Nevertheless, the same research demonstrates that with improvements of oil extraction methodology, macroalgae could be considered a good residual biomass usable for biofuel production [9]. The aim of this study is to evalu- 
ate, in the Orbetello lagoon, oil extraction efficiency of different extraction procedures also comparing results obtained by the extraction of four different common macroalgae (Chaetomorpha linum, Ulva laetevirens, Valonia aegagrophyla, Gracilariopsis longissima) and one phanerogams species (Ruppia cirrhosa).

\section{Materials and Methods}

\subsection{Macroalgae System}

The Orbetello lagoon is a meso-eutrophic [10] transitional ecosystem located along the Southern Tuscan coast $\left(42^{\circ} 25^{\prime}-42^{\circ} 29^{\prime}\right.$ Lat. North; $11^{\circ} 10^{\prime}-11^{\circ} 17^{\prime}$ Long. East) of the Central Tyrrhenian Sea. It covers $25.25 \mathrm{~km}^{2}(1.20 \mathrm{~m}$ average depth ranging from $0.30-1.70 \mathrm{~m}$ ); an artificial dam divides the lagoon into two connected basins referred to as Western and Eastern, covering 15.25 and $10.00 \mathrm{~km}^{2}$, respectively. The presence of the dam reduces water circulation and water exchanges between the two basins, while not significant fluxes of floating macroalgae throughout the dam are reported by the literature [11]. The Orbetello lagoon is characterized by a high level of human impact due to both historical and recent human activities responsible for the bioavailable nutrient and chemical distributions within the system [12]. Among others, the major human activities producing environmental impacts are: 1) summer tourism [13,14]; 2) runoff from urban areas [15,16]; 3) debris and dusts from a fertilizer production plant (no longer in operation) [17]; 4) effluents from municipal wastewater treatment plants [13]; and 5) discharges from fish farming activities [18, 19]. Although localized hot-spot sources of human origin are significant, widespread natural ones (including inflows from the Albegna river) are also relevant [12]. Frequent macrophyte fluctuations have been documented in this ecosystem over time [20] with excessive macroalgae production recorded in recent years [20,21]. Due to the occurrence of frequent dystrophic crisis the Italian Government imposed a special Committee for the management of this ecosystem founding exceptional actions to prevent further ecological alterations. Among management actions adopted by the special Committee for the Orbetello lagoon management, the harvesting of floating biomasses was adopted to reduce the risk of the dystrophy occurrence. Four macroalgae species are dominant in Orbetello lagoon: Chaetomorpha linum (O.F. Müller) [22], Ulva laetevirens [23], Valonia aegagrophyla [22], and Rhodophyta Gracilariopsis longissima (S.G. Gmelin) [24]. Concerning phanerogams, the highest diffused species is represented by Ruppia cirrhosa [12]; dead leaves of $R$. cirrhosa float in lagoon water and are mechanically harvested at the end of summer with macroalgae biomasses by harvesting boats. Collected biomasses are locally stor- age, dried in a special structure and treated as organic potentially highly polluted waste by the local management Authority [8] with notable additional economical expenses for the Italian Government.

\subsection{Macroalgae Collection and Oil Extraction}

Biomass sampling was performed within March and October to consider biomass variability of each species and natural oil content due to the season. Triplicate samples were prepared for each algae species and lipids were extracted by the Accelerate Solvent Extraction (ASE) technique using an ASE 200 purchased by the Dionex Company. The advantage evidenced by this technique is related to the possibility of improving extraction efficiency obtained by Soxhlet extractor or sonication techniques, reducing both time occurring for the process and solvents quantities. Furthermore, all the process occurs under high pressure levels in a closed pressurized system reducing solvent vaporization and releases in the environment. This technique was chosen in this research because it is suitable to represent an industrial extraction process for the biodiesel production, during which quantities of solvent used and wasted must be minimized. Four different extraction procedures were tested both in dried and wet tissues to evaluate the effect induced by pressure, solvent mixture, and water content of tissues on the global efficiency of the lipid extraction. Instrumental parameters set for the extraction are reported in Table 1. The method $n$. 1 is the selective Dionex method proposed for the extraction of persistent organic pollutants from animal tissues [25], while the others are opportune variations of the method n. 1. Some parameters were fixed during experiments. In particular, heat-up time was set at 5 minutes, static time was set at 5 minutes imposing 2 static cycle for each sample, flush volume was $60 \%$, purge time 90 seconds, and temperature of extraction was $100^{\circ} \mathrm{C}$. Extraction cells were filled with diatoms dust to minimize solvent volume needed to fill and pressurized the cell. Organic phase extracted from each sample was collected in pre-weighted and pre-cleaned glass vial, evaporated to dry and the total lipid content was determined as weight percentage by double-weighting.

Table 1. Instrumental parameters set for the extractions.

\begin{tabular}{cccc}
\hline Parameter & Pressure & \multicolumn{2}{c}{ Solvent } \\
\hline & psi & Type & percentage \\
\hline Method 1 & 1500 & Hexane & 100 \\
Method 2 & 2000 & Hexane & 100 \\
Method 3 & 1500 & Hexane-Dichloromethane & $50-50$ \\
Method 4 & 1500 & Hexane-Dichloromethane & $30-70$ \\
\hline
\end{tabular}

$1 \mathrm{psi}=6894.76 \mathrm{~Pa}$. 


\section{Results}

Obtained extracts produced by the application of described methods are exemplified in Figure 1. A comparison among extraction efficiencies obtained by the use of the Method 3 for some of the tested species is reported in Table 2; a comparison among values obtained extracting both wet and dry tissues is, also, evidenced. In Figure 2, lipid percentages extracted from dried tissues of all considered species are summarized. Maximum extracted lipids value is $2.2 \%$ d.w. While minimum is $0.12 \%$ d.w ( $R$. cirrhosa). Results evidence as the major extraction efficiency of lipids is observed using dried tissues. Furthermore, the extraction of dried tissues allowed to recovery a larger amount of pigments than extraction performed on wet tissues (Figure 1). Reproducibility of observed performances is higher in dried samples than wet tissues probably due to the water interference occurred during the extraction procedure of the latter. Pressure affects the extraction process determining, with only one exception (V. aegagrophyla) better performance at 2000 psi rather than at 1500 psi. Concerning species, the highest effi-

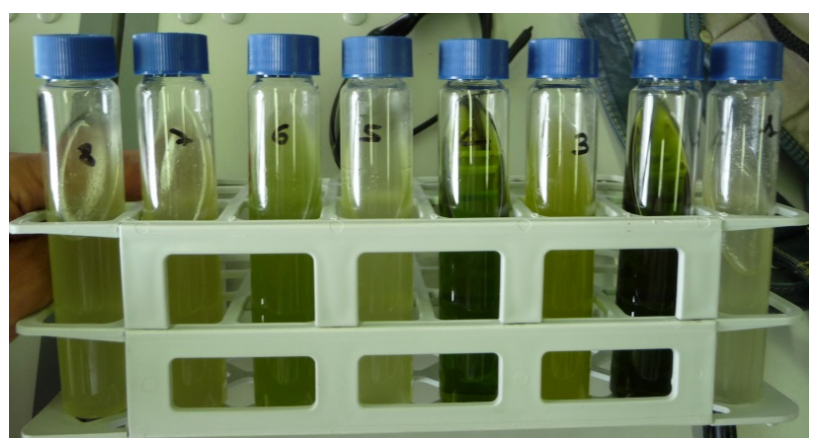

Figure 1. Extracts obtained by the ASE procedure using the different tested Methods. Notes: $1=V$. aegagrophyla wet tissues (w.w.); 2 = V. aegagrophyla dried tissues (d.w.); $3=C$. linum (w.w.); 4 = C. linum (d.w.); $5=$ R. cirrhosa (w.w.); 6 = R. cirrhosa (d.w.); $7=$ G. longissima (w.w.); $8=$ G. longissima (d.w.) extracted with the same method (Method 3).

Table 2. Reproducibility of replicated extractions $(n=5)$ performed with the Method 3.

\begin{tabular}{cccccccc}
\hline Dry tissues & $\mathrm{R} 1$ & $\mathrm{R} 2$ & $\mathrm{R} 3$ & $\mathrm{R} 4$ & $\mathrm{R} 5$ & Mean & $\mathrm{SD}$ \\
\hline V. aegagrophyla & 1.48 & 1.52 & 1.45 & 1.61 & 1.57 & 1.53 & 0.07 \\
C. linum & 0.39 & 0.30 & 0.35 & 0.28 & 0.33 & 0.33 & 0.04 \\
R. cirrhosa & 0.12 & 0.15 & 0.16 & 0.19 & 0.12 & 0.15 & 0.03 \\
G. longissima & 0.21 & 0.25 & 0.27 & 0.31 & 0.20 & 0.25 & 0.04 \\
\hline Wet tissues & $\mathrm{R} 1$ & $\mathrm{R} 2$ & $\mathrm{R} 3$ & $\mathrm{R} 4$ & $\mathrm{R} 5$ & Mean & $\mathrm{SD}$ \\
\hline V. aegagrophyla & 1.95 & 1.73 & 1.99 & 1.67 & 1.71 & 1.81 & 0.15 \\
C. linum & 0.30 & 0.09 & 0.23 & 0.05 & 0.15 & 0.16 & 0.10 \\
R. cirrhosa & 0.13 & 0.39 & 0.27 & 0.11 & 0.41 & 0.26 & 0.14 \\
G. longissima & 0.27 & 0.49 & 0.52 & 0.29 & 0.34 & 0.38 & 0.12 \\
Control & $<0.01$ & $<0.01$ & $<0.01$ & $<0.01$ & $<0.01$ & $<0.01$ & n.c. \\
\hline
\end{tabular}

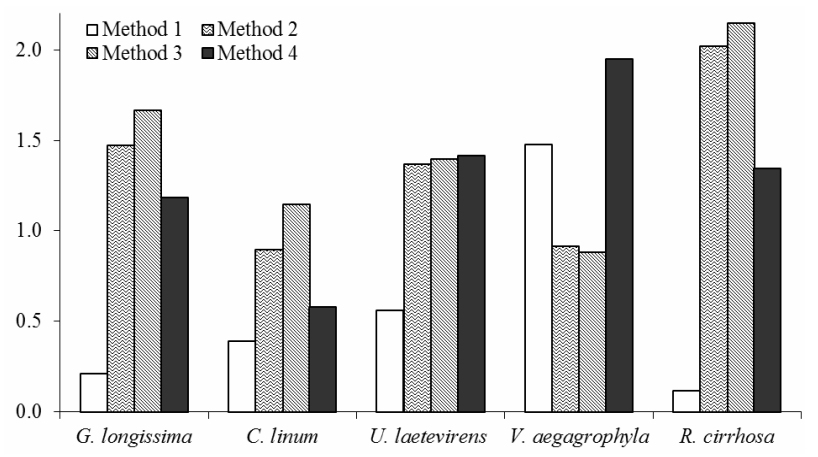

Figure 2. Average lipids (\%) extracted from dried tissues of tested species using different extraction methods.

ciency is recorded for $R$. cirrhosa (Method n. 3) while $C$. linum evidences the lowest lipid content. Comparing tested methods, with the exception of $V$. aegagrophyla, better extraction methods is represented by the Method n. 3 . Average lipid percentage extracted in this study from dried G. longissima and C. linum tissues are higher than values reported by the literature (extracting wet tissues with different methods) for the same species or genus $[9,26$, 27]. Comparing results obtained in this research by the extraction of wet tissues, lipid percentages are on average about two times higher in G. longissima and comparable to those recorded in C. linum by Bastianoni et al. [9].

\section{Discussion}

The main sources of greenhouse gases due to human activity are represented by burning of fossil fuels [28]. The principal of the contributions to the total amount of fossil fuel combustion (with percentage contributions for 20002004) are represented by the liquid fuels (36\%), solid fuels (35\%) and gaseous fuels (20\%) [29]. In European Union, transport activities and energy production constitute respectively $20 \%$ and $60 \%$ of total emissions [3]. Biofuels production is expected to offer new opportunities to diversify income and fuel supply sources, to promote employment in rural areas, to develop long term replacement of fossil fuels, and to reduce greenhouse gases emissions, boosting the decarbonisation of transportation fuels and increasing the security of energy supply [3]. Research in energetic fields is focalized to the development of possible alternatives to fossil fuels. The main alternative to diesel fuel in EU is biodiesel representing 82\% of total biofuels production [30] and is still growing in Europe, Brazil, and United States, based on political and economic objectives. Biodiesel produced in United States is principally produced by the extraction of soybean even if other sources as well as palm oil, maize or oil wastes are used to produce biofuels with variable efficiencies in terms of oil produced per hectare [6]. The use of palm oil in the production of biodiesel has led to concern that 
the need for fuel is being placed ahead of the need for food, leading to malnourishment in developing nations. This is known as the food versus fuel debate [31]. The need to improve eco-sustainability of the energy production process stimulates researches on biofuels production from wastes and renewal biomasses as well as algae. A lot of experiences have been performed on the evaluation of energetic efficiency of the oil extraction process from microalgal artificial cultures [3] due to the high percentage of lipids content in unicellular species ranging within $4 \%-22 \%$ d.w. [32]. On the contrary, few data have been collected on the efficiency obtained by the extraction of macroalgae and phanerogams species. In spite of that, macroalgae are naturally growing in coastal eutrophic ecosystems producing great quantities of biomasses with any human effort $[9,12,20]$. The advantages obtainable from the use of such resources are twice: 1 ) the possibility to avoid ecological, economical and energetic costs comes from the cultivation of biomasses; 2) the chance to transform a notable cost (the management of macroalgal biomasses) in resource. Furthermore, algae are biodegradable, relatively harmless to the environment if spilled and, differently than maize and palm, do not require the use of pesticides and can be produced without subtracting lands for food productions.

The great part of extractable oils from macroalgae biomasses are utilizable for the production of biodiesel $[1,6]$. A great advantage coming from the use of macroalgae for the production of biodiesel is represented by the absence of sulfur and, consequently, by the energy conversion efficiency similar to petrol. Furthermore, the absence of sulfur reduces particulates, hydrocarbons, carbon monoxides and sulfur dioxides production during combustion processes [33]. An important limit for the extraction of biodiesel by macroalgae is represented by the lower efficiency of lipids extractions by tissues.

Results obtained in this paper evidence that Accelerate Solvent Extraction technique could significantly improve the total amount of lipid extracted from macrophytes tissues compared to results reported by the literature for other methods $[9,26,27]$. Better performances are associated to the extraction of dried tissues due to the fact that intracellular water reduces the extraction efficiency of hydrophobic solvents as well as hexane. Pressure improves recoveries probably to the better solvent penetration within the macrophytes structure and the cell wall. The mixture of hexane Dichloromethane (DCM) with the highest percentage of DCM represents the better method for the extraction of species characterized by a high water content in tissues as well as $V$. aegagrophyla. In spite of results obtained in this research are notably higher than values recorded by further experiments performed using Soxhlet extraction procedures or sonication methods, lipids recovery percentages are notably lower than values obtain- ed by the extraction of microalgae (on average 1.5\% d.w.). Considering average recovery rates recorded in this study and an annual production of 6774 tons of macrophytes [8], in the Orbetello lagoon, an industrial plant based on ASE extraction process could produce 135.48 tons of lipids and $6.7 \times 10^{7} \mathrm{~m}^{3}$ of hazardous solvents to manage.

The economical sustainability of this practice could represent some industrial interest only if included into a multi-step procedure. In fact, biomass production is not expensive but harvesting, drying, and extraction processes represent important costs that have to be overcome by the sale of obtained products. First of all, volumes of extraction solvents have to be notably reduced to reduce costs associated to their disposal. Probably a useful strategy is to develop a productive industrial plant able to obtained by a multi-step procedure not only lipids for the biofuel production but, also, other interesting commercial products as well as pigments [32]. Furthermore, macroalgae residues obtained at the end of the multi-step extraction process, could be suitable as biosorbent for the removal of metal or metalloid species, compounds and particulates for the treatment of high volume low-concentration complex wastewaters [34].

\section{Conclusion}

Accelerate Solvent Extraction technique evidences a notably better extraction performance than other methods tested by the literature as well as Soxhlet or sonication even if observed average values are close to $2 \%$ d.w. This extraction efficiency is far to be encouraging to develop a sustainable industrial process on an economic point of view. In spite of that some results are interesting and could be useful for further researches on macrophytes and biodiesel production. To the best of our knowledge, for the first time, the lipid content of some of tested macrophytes (Ulva laetevirens, Valonia aegagrophyla, Ruppia cirrhosa) has been measured. Water content in tissue reduces extraction efficiency whereas pressure and higher percentages of polar solvents increase lipids recoveries.

\section{Acknowledgements}

Authors are grateful to the Orbetello Pesca Lagunare society to their support in field activities and to Dr. Mauro Lenzi for the support during species identification. Authors are grateful to Bianca Salce and Angela Tozzi for the language revision.

\section{REFERENCES}

[1] E.-H. Belarbi, E. Molina and Y. Chisti, “A Process for High Yield and Scaleable Recovery of High Purity Eicosapentaenoic Acid Esters from Microalgae and Fish Oil," 
Enzyme and Microbial Technology, Vol. 26, 2000, pp. 516-529. http://dx.doi.org/10.1016/S0141-0229(99)00191-X

[2] M. J. Cooney, G. Young and R. Pate, "Bio-Oil from Photosynthetic Microalgae: Case Study,” Bioresource Technology, Vol. 102, No. 1, 2011, pp. 166-177. http://dx.doi.org/10.1016/j.biortech.2010.06.134

[3] T. M. Mata, A. A. Martins and N. S. Caetano, "Microalgae for Biodiesel Production and Other Applications: A Review," Renewable and Sustainable Energy Reviews, Vol. 14, No. 1, 2010, pp. 217-232. http://dx.doi.org/10.1016/j.rser.2009.07.020

[4] S. Bastianoni and N. Marchettini, "Ethanol Production from Biomass: Analysis of Process Efficiency and Sustainability,” Biomass \& Bioenergy, Vol. 11, No. 5, 1996, pp. 411-418. http://dx.doi.org/10.1016/S0961-9534(96)00037-2

[5] J. Singh and S. Gu, "Commercialization Potential of Microalgae for Biofuels Production,” Renewable and Sustainable Energy Reviews, Vol. 14, No. 9, 2010, pp. 25962610. http://dx.doi.org/10.1016/j.rser.2010.06.014

[6] Y. Chisti, "Biodiesel from Microalgae," Biotechnology Advances, Vol. 25, No. 3, 2007, pp. 294-306. http://dx.doi.org/10.1016/j.biotechadv.2007.02.001

[7] R. Harun, M. Singh, G. M. Forde and M. K. Danquah, "Bioprocess Engineering of Microalgae to Produce a Variety of Consumer Products,” Renewable and Sustainable Energy Reviews, Vol. 14, No. 3, 2010, pp. 1037-1047. http://dx.doi.org/10.1016/j.rser.2009.11.004

[8] A. Ludovico, "La Laguna di Orbetello, Studi, Ricerche, Criteri e Modalità di Intervento in Quattro anni di Gestione Commissariale 2003-2006,” Presidenza del Consiglio Dei Ministri, Commissario Delegato al Risanamento Ambientale della Laguna di Orbetello, Rolando Di Vincenzo, 2006.

[9] S. Bastianoni, F. Coppola, E. Tiezzi, A. Colacevich, F. Borghini and S. Focardi, "Biofuel Potential Production from the Orbetello Lagoon Macroalgae: A Comparison with Sunflower Feedstock,” Biomass and Bioenergy, Vol. 32, No. 7, 2008, pp. 619-628. http://dx.doi.org/10.1016/j.biombioe.2007.12.010

[10] A. Specchiulli, S. Focardi, M. Renzi, T. Scirocco, L. Cilenti, P. Breber and S. Bastianoni, "Environmental Heterogeneity Patterns and Assessment of Trophic Levels in Two Mediterranean Lagoons: Orbetello and Varano, Italy," Science of the Total Environment, Vol. 402, No. 2-3, 2008, pp. 285-298. http://dx.doi.org/10.1016/j.scitotenv.2008.04.052

[11] M. Innamorati and C. Melillo, "Studio Della Laguna di Orbetello: Ecologia ed Aspetti Economici,” Report in Italian Language, Laboratorio di Ecologia, Dipartimento di Biologia Vegetale, Università di Firenze, 2004. http://eprints.unifi.it/archive/00001260/

[12] A. Giovani, E. Mari, A. Specchiulli, L. Cilenti, T. Scirocco, P. Breber, M. Renzi, S. E. Focardi and M. Lenzi, "Factors Affecting Changes in Phanerogams Distribution Patterns of Orbetello Lagoon, Italy,” Transitional Waters Bulletin, Vol. 4, No. 1, 2010, pp. 35-52.
[13] M. Renzi, G. Perra, C. Guerranti, E. Franchi and S. Focardi, "Abatement Efficiency of Municipal Wastewater Treatment Plants Using Different Technologies (Orbetello Lagoon, Italy)," International Journal of Environment and Health, Vol. 3, No. 1, 2009, pp. 58-70. http://dx.doi.org/10.1504/IJENVH.2009.022905

[14] M. Renzi, A. Giovani and S. E. Focardi, "Water Pollution by Surfactants: Fluctuations Due to Tourism Exploitation in a Lagoon Ecosystem,” Journal of Environmental Protection, Vol. 3, 2012, pp. 1004-1009. http://dx.doi.org/10.4236/jep.2012.39116

[15] G. Perra, M. Renzi, C. Guerranti aaand S. E. Focardi, "Polycyclic Aromatic Hydrocarbons Pollution in Sediments: Distribution and Sources in a Lagoon System (Orbetello, Central Italy)," Transitional Waters Bulletin, Vol. 3, No. 1, 2010, pp. 45-58.

[16] A. Specchiulli, M. Renzi, G. Perra, L. Cilenti, T. Scirocco, M. Florio, S. Focardi, P. Breber and S. Focardi, "Distribution and Sources of Polycyclic Aromatic Hydrocarbons (PAHs) in Surface Sediments of Some Italian Lagoons Exploited for Aquaculture and Fishing Activities,” International Journal of Environmental Analytical Chemistry, Vol. 91, No. 4, 2011, pp. 367-386. http://dx.doi.org/10.1080/03067310903434758

[17] S. Focardi, M. Mariottini, M. Renzi, G. Perra and S. Focardi, "Anthropogenic Impacts on the Orbetello Lagoon Ecosystem,” Toxicology and Industrial Health, Vol. 25, No. 4-5, 2009, pp. 365-371. http://dx.doi.org/10.1177/0748233709106465

[18] S. Porrello, M. Lenzi, G. Ferrari, E. Persia and P. Tomassetti, "Loading of Nutrient from a Land Based Fish Farm (Orbetello, Italy) at Different Time,” Aquatic International, Vol. 13, No. 1-2, 2005, pp. 97-108. http://dx.doi.org/10.1007/s10499-004-9027-1

[19] M. Renzi, M. Lenzi, E. Franchi, A. Tozzi, S. Porrello, S. Focardi and S. E. Focardi, "A Forecast Method of Seagrass Meadow Compatibility in Coastal Shallow Water Bottom,” International Journal of Environment and Health, Vol. 1, No. 3, 2007, pp. 360-374. http://dx.doi.org/10.1504/IJENVH.2007.017867

[20] M. Lenzi, R. Palmieri and S. Porrello, "Restoration of the Eutrophic Orbetello Lagoon (Tyrrhenian Sea, Italy): Water Quality Management,” Marine Pollution Bulletin, Vol. 46, No. 12, 2003, pp. 1540-1548. http://dx.doi.org/10.1016/S0025-326X(03)00315-1

[21] M. Lenzi, "Experiences for the Management of Orbetello Lagoon: Eutrophication and Fishing," Science of the Total Environment, Vol. 5, No. S1, 1992, pp. 1189-1198.

[22] F. T. Kützing, "Phycologia Germanica, d. i. Deutschlands Algen in Bündigen Beschreibungen. Nebst einer Anleitung zum Untersuchen und Bestimmen Dieser Gewächse für Anfänger,” 1845, pp. 1-340.

[23] J. E. Areschoug, "Phyceae Novae et Minus Cognitae in Maribus Extraeuropaeis Collectae,” Nova Acta Regiae Societatis Scientiarum Upsaliensis, Vol. 3, No. 1, 1854, pp. 329-372.

[24] M. Steentoft, L. M. Irvine and W. F. Farnham, "Two Terete Species of Gracilaria and Gracilariopsis (Gracilaria- 
les, Rhodophyta) in Britain,” Phycologia, Vol. 34, No. 2, 1995, pp. 113-127.

http://dx.doi.org/10.2216/i0031-8884-34-2-113.1

[25] Dionex, "Solvent Extraction of PCBs from Fish Tissue Using Accelerated Solvent Extraction (ASE),” 1997, Application note 322, p. 4.

[26] P. V. Devi Prasad, "A Seasonal Study of the Red Seaweeds Soliera Tenera and Three Species of Gracilaria from Jamaica," Hydrobiologia, Vol. 140, No. 2, 1986, pp. 167171. http://dx.doi.org/10.1007/BF00007571

[27] S. V. Khotimchenko, "Lipids from the Marine Alga Gracilaria Verrucosa," Chemistry of Natural Compounds, Vol. 41, No. 3, 2005, pp. 285-288. http://dx.doi.org/10.1007/s10600-005-0130-y

[28] IPCC, S. Solomon, D. Qin, M. Manning, Z. Chen, M. Marquis, K. B. Averyt, M. Tignor and H. L. Miller, “Chapter 7. Couplings between Changes in the Climate System and Biogeochemistry," Climate Change 2007: The Physical Science Basis. Contribution of Working Group I to the Fourth Assessment Report of the Intergovernmental Panel on Climate Change, Cambridge University Press, Cambridge and New York, 2007.

[29] M. R. Raupach, G. Marland, P. Ciais, C. Le Quere, J. G. Canadell, G. Klepper and G. B. Field, "Global and Regional Drivers of Accelerating $\mathrm{CO}_{2}$ Emissions," Procee- dings of the National Academy of Sciences of the USA, Vol. 104, No. 24, 2007, pp. 10288-10293. http://dx.doi.org/10.1073/pnas.0700609104

[30] K. Bozbas, "Biodiesel as an Alternative Motor Fuel: Production and Policies in the European Union," Renewable and Sustainable Energy Reviews, Vol. 12, No. 2, 2008, pp. 542-552. http://dx.doi.org/10.1016/j.rser.2005.06.001

[31] M. K. Lam, K. T. Tan, K. T. Lee and A. R. Mohamed, "Malaysian Palm Oil: Surviving the Food versus Fuel Dispute for a Sustainable Future,” Renew Sustain Energy Review, Vol. 13, No. 6-7, 2008, pp. 1456-1464. http://dx.doi.org/10.1016/j.rser.2008.09.009

[32] P. Spolaore, C. Joannis-Cassan, E. Duran and A. Isambert, “Commercial Applications of Microalgae. Review," Journal of Bioscience and Bioengineering, Vol. 101, No. 2, 2006, pp. 87-96. http://dx.doi.org/10.1263/jbb.101.87

[33] M. A. Delucchi, “A Lifecycle Emissions Model (LEM): Lifecycle Emissions from Transportation Fuels; Motor Vehicles, Transportation Modes, Electricity Use, Heating and Cooking Fuels,” Main Report UCD-ITS-RR-03-17, 2003.

[34] J. Wang and C. Cheng, "Biosorbents for Heavy Metals Removal and Their Future,” Biotechnology Advances, Vol. 27, No. 2, 2009, pp. 195-226. http://dx.doi.org/10.1016/j.biotechadv.2008.11.002 